\title{
Length-weight relationship of selected freshwater fish species from three diverse ecological regimes in India
}

\author{
KULDEEP KUMAR LAL*, BRAJ KISHOR GUPTA, ARVIND KUMAR DWIVEDI, RAJEEV \\ KUMAR SINGH, SURESH CHANDRA, VINDHYA MOHINDRA, LALIT KUMAR TYAGI \\ AMIT SINGH BISHT, RAMA SANKAR SAH, AJAY KUMAR PATHAK AND J. K. JENA \\ National Bureau of Fish Genetic Resources, Canal Ring Road, P. O. Dilkusha, Lucknow - 226 002, Uttar Pradesh, India \\ *Network of Aquaculture Centers in Asia-Pacific, Kasetsart University Campus, Bangkok 10900, Thailand \\ e-mail:kuldeepklal@gmail.com
}

\begin{abstract}
Length-weight relationship and condition factor in 57 freshwater fish species of 19 families and 38 genera from various rivers, and lakes of different climatic zones in India were studied. The estimates (total 67) for the parameter b of the length-weight relationship ranged between 1.422 and 3.917, with a mean value of 2.994. Correlation coefficient was found to be highly significant $\left(\mathrm{r}^{2}>0.90\right)$ in all except for Crossocheilus latius latius, Acanthocobitis botia and Garra lamta. Growth was found to be isometric $(b=3)$ in 32 species, positively allometric $(b>3)$ in 21 species and negatively allometric $(b<3)$ in 14 species. It was also found that some species exhibited variations in their growth pattern in different habitats, which showed the influence of preference and availability of suitable habitat conditions.
\end{abstract}

Keywords: Allometric growth, Condition factor, Freshwater fishes, India, Isometric growth, Length-weight relationship

Fisheries management and research often require the use of biometric relationships in order to transform data collected in the field into appropriate indices (Ecoutin and Albaret, 2003). Morphometry is very important in the estimation of the length and age structures, population dynamics (Krause et al., 1998), growth, mortality rates and well-being of the fish (Kohler et al., 1995). Knowledge of the relationship between weight and length is essential to predict production and biomass of a fish population (Dulcic and Kraljevic, 1996), allowing morphological comparisons among species or among populations of the same species from different habitats and/or geographical regions (Moutopoulos and Stergiou, 2002; Santos et al., 2002). Length-weight relationship (LWR) is frequently used to follow seasonal variations in fish growth and to estimate condition indices (Safran, 1992; Richter et al., 2000).

The condition factor $(\mathrm{K})$ of fish is crucial in fishery biology (Weatherly and Gill, 1987), which represents well being of the fish (Le Cren, 1951, Bagenal and Tesch, 1978; Lizama et al., 2002). Condition factor is also an index to understand the lifecycle of the fish by referring to the coefficient values derived from the LWR relationship data (Schneider et al., 2000). This parameter could also be used to determine the status of the aquatic ecosystem in which the fish lives (Luff and Bailey, 2000; Anene, 2005).

Regression data are available for most of the European and North American freshwater fishes, but such data is still lacking for many tropical fish species (De Silva, 1991; Froese and Pauly, 2013). The present study estimates differences in growth patterns on the basis of LWR for 57 species belonging to 19 families having economic and conservation importance. Out of these, limited data on LWR is available for 27 species in FishBase (Froese and Pauly, 2013).

The collection sites were located in different river systems of India with unrelated climate conditions, viz., Ravi Rriver in upland Himalayan region (Himachal Pradesh), Som River and Jaisamand Lake in arid zone of north-west India (Rajasthan) and Godavari River in semi-arid Deccan region. Ravi River, a major tributary of the Indus River, originates from Bara Bangahal (at an elevation of $4229 \mathrm{~m}$; lat. $32^{\circ} 33 \mathrm{~N}$; long. $76^{\circ} 07 \mathrm{E}$ ) in Chamba region of Himachal Pradesh. In river Som and Jaisamand Lake, the sampling sites were located at Udaipur (Rajasthan). In river Godavari and its tributaries (Penganga and Pranahita), the major collection sites were at Adilabad (Andhra Pradesh). River Som is part of Mahi river system, which originates from Som Village $\left(24^{\circ} 11^{`} \mathrm{~N} ; 7^{\circ} 19^{`} \mathrm{E}\right.$, altitude $547 \mathrm{~m}$ ) of Rajasthan. Lake Jaisamand is Asia's second-largest artificial lake with an area of $87 \mathrm{~km}^{2}$ and situated in Rajasthan at $951 \mathrm{ft}$ above sea level $\left(24^{\circ} 13^{\prime} \mathrm{N} ; 74^{\circ} 59^{\prime} \mathrm{E}\right)$. River Godavari is a major waterway in the central India, originating in the Western Ghats in Nashik and flowing eastward across the Deccan 
plateau through the state of Maharashtra. It is also known as Dakshin Ganga and enters at Basara in Adilabad region in the state of Telangana. In Adilabad, Godavari River flows in southern boundary and covers around $240 \mathrm{~km}$ stretch $\left(18^{\circ} 52 \mathrm{~N} ; 77^{\circ} 57 \mathrm{E}\right.$, altitude 332 to $\left.95 \mathrm{~m}\right)$. Penganga and Pranahita are two major tributaries which join Godavari at Adilabad.

A total of 1901 fish samples were collected from different sampling locations in each of the selected region, to cover all representative habitats. Samples were collected twice a year (excluding the rainy seasons) during August 2010 to July 2013 by experimental fishing using suitable fishing gear. Total length (TL) of each fish was taken from the tip of the snout (mouth closed) to the extended tip of the caudal fin (to nearest $0.1 \mathrm{~cm}$ ) using digital caliper (Mitutoyo Corp., Japan) and weighed to the nearest $0.1 \mathrm{~g}$ (total weight) by digital weighing machine. Identification of species was done following Talwar and Jhingran (1991) and Jayaram (1999). Representative samples were preserved in $10 \%$ formalin solution. Some species were far more abundant than others, and the sample size varied accordingly.All data were log-transformed and the ensuing least square linear regressions (Zar, 1984) were derived, with the weight as the dependent variable following the well known $L W R, \log W=\log a+b \log L$ (Beckman, 1948). Linear regressions on log-transformed data were highly significant $(\mathrm{p}<0.001)$ for all species studied. The degree of well-being or relative robustness of the fish is expressed by 'coefficient of condition' (also known as condition factor). Variations in the fish's coefficient of condition primarily reflect the state of sexual maturity and degree of nourishment. The condition factor $\mathrm{K}$ (Fulton, 1904) was estimated as: $\mathrm{K}=100 \mathrm{~W} / \mathrm{L}^{3}$. All statistical analyses were performed using Microsoft excel (ver. 2007) and GraphPad Prism software version 6.0. To compare the variations among different regions, 95\% confidence limits were used.

The best-represented family was Cyprinidae (27 species), followed by Bagridae ( 5 species), Siluridae (3 species), and Channidae (3 species). The remaining families were each represented by a single species. Sample size, minimum and maximum length and maximum reported length (Froese and Pauly, 2013), for each species as well as LWR, coefficient of determination $\left(r^{2}\right)$, slope of regression (b), 95\% confidence range for b, intercept of regression (a) with $95 \%$ confidence range, growth type and condition factor are presented in Table 1. A total of 67 estimates were derived for the 57 species. The estimates

Table 1. Descriptive statistics and estimated parameters of length-weight relationship $\left(\mathrm{W}=\mathrm{a} \mathrm{L}^{\mathrm{b}}\right)$, condition factor and type of growth for fishes collected from different river systems in India

\begin{tabular}{|c|c|c|c|c|c|c|c|c|c|c|c|}
\hline \multirow{2}{*}{ Family } & \multirow{2}{*}{ Species } & \multirow{2}{*}{$\mathrm{n}$} & \multicolumn{2}{|c|}{ Total length $(\mathrm{cm})$} & \multirow{2}{*}{$\begin{array}{l}\text { Max. known } \\
\text { length }(\mathrm{cm})^{*}\end{array}$} & \multicolumn{5}{|c|}{ Regression parameters } & \multirow{2}{*}{$\mathrm{K}$} \\
\hline & & & Min. & Max. & & Anti $\log$ a & $\mathrm{b}$ & $95 \% \mathrm{CI}$ of a & $95 \% \mathrm{CI}$ of $\mathrm{b}$ & $\mathrm{r}^{2}$ & \\
\hline Anguillidae & $\begin{array}{l}\text { Anguilla bengalensis } \\
\text { bengalensis (A) }\end{array}$ & 56 & 21.0 & 115.0 & 200.0 & 0.0366 & 3.338 & -3.703 to -2.912 & 3.108 to 3.569 & 0.94 & 0.95 \\
\hline Notopteridae & Notopterus notopterus (A) & 65 & 12.0 & 33.0 & 60.0 & 0.0029 & 3.326 & -2.693 to -2.368 & 3.206 to 3.447 & 0.98 & 0.82 \\
\hline \multirow[t]{22}{*}{ Cyprinidae } & Labeo bata (A) & 09 & 15.5 & 36.0 & 61.0 & 0.0046 & 3.253 & -2.469 to -2.212 & 3.157 to 3.348 & 0.99 & 1.00 \\
\hline & Labeo boggut (A) & 26 & 11.5 & 22.2 & 29.0 & 0.0173 & 2.796 & -1.974 to -1.551 & 2.623 to 2.968 & 0.98 & 0.98 \\
\hline & Labeo boggut (B) & 61 & 9.7 & 27.0 & 29.0 & 0.0098 & 3.028 & -2.086 to -1.935 & 2.966 to 3.090 & 0.99 & 1.06 \\
\hline & Labeo calbasu (A) & 32 & 9.5 & 40.0 & 90.0 & 0.0096 & 3.084 & -2.229 to -1.802 & 2.935 to 3.233 & 0.98 & 1.28 \\
\hline & Labeo dero $(\mathrm{C})$ & 30 & 23.0 & 38.5 & 75.0 & 0.0099 & 2.952 & -2.375 to -1.634 & 2.710 to 3.194 & 0.96 & 0.86 \\
\hline & Labeo fimbriatus (A) & 101 & 16.5 & 33.0 & 91.0 & 0.0049 & 3.250 & -2.489 to -2.115 & 3.118 to 3.382 & 0.96 & 1.20 \\
\hline & Labeo gonius (A) & 14 & 15.0 & 28.0 & 150.0 & 0.0109 & 2.989 & -2.295 to -1.632 & 2.735 to 3.242 & 0.98 & 1.08 \\
\hline & Labeo rohita (A) & 13 & 19.5 & 41.0 & 200.0 & 0.0071 & 3.154 & -2.641 to -1.656 & 2.816 to 3.493 & 0.97 & 1.20 \\
\hline & Labeo dyocheilus (A) & 08 & 29.5 & 42.5 & 90.0 & 0.5395 & 1.522 & -0.1720 to 0.7086 & 1.241 to 1.804 & 0.74 & 0.94 \\
\hline & Catla catla (A) & 09 & 17.5 & 42.5 & 182.0 & 0.0033 & 3.425 & -2.935 to -2.037 & 3.128 to 3.723 & 0.99 & 1.44 \\
\hline & Cirrhinus mrigala (B) & 20 & 20.5 & 50.5 & 100.0 & 0.0022 & 3.456 & -2.997 to -2.318 & 3.218 to 3.695 & 0.98 & 1.10 \\
\hline & Cirrhinus reba (A) & 20 & 16.0 & 28.0 & 30.0 & 0.0021 & 3.514 & -2.988 to -2.360 & 3.275 to 3.754 & 0.98 & 1.01 \\
\hline & Labeo sp. (B) & 20 & 14.5 & 37.0 & - & 0.0090 & 3.074 & -2.210 to -1.881 & 2.950 to 3.199 & 0.99 & 1.13 \\
\hline & Tor khudree (A) & 14 & 24.0 & 50.5 & 50.0 & 0.0036 & 3.311 & -2.864 to -2.014 & 3.028 to 3.595 & 0.98 & 1.07 \\
\hline & Tor putitora $(\mathrm{C})$ & 43 & 21.0 & 59.0 & 275.0 & 0.0049 & 3.145 & -2.489 to -2.135 & 3.031 to 3.258 & 0.99 & 0.82 \\
\hline & Tor putitora $(\mathrm{B})$ & 24 & 11.5 & 45.0 & 275.0 & 0.0206 & 2.764 & -2.012 to -1.359 & 2.501 to 3.026 & 0.96 & 1.08 \\
\hline & Tor tor (A) & 27 & 10.0 & 47.0 & 200.0 & 0.0129 & 2.940 & -2.014 to -1.762 & 2.836 to 3.044 & 0.99 & 1.10 \\
\hline & Tor tor $(\mathrm{B})$ & 13 & 6.5 & 24.2 & 200.0 & 0.0098 & 3.038 & -2.154 to -1.861 & 2.902 to 3.174 & 0.99 & 1.08 \\
\hline & Salmophasia bacaila (B) & 18 & 9.0 & 16.0 & 18.0 & 0.0026 & 3.334 & -2.973 to -2.186 & 2.950 to 3.718 & 0.95 & 0.59 \\
\hline & Barilius bendelisis (C) & 13 & 10.2 & 13.3 & 22.7 & 0.0337 & 2.586 & -1.928 to -1.017 & 2.163 to 3.008 & 0.94 & 1.21 \\
\hline & Hypselobarbus curmuca (A) & 38 & 12.0 & 29.5 & 120.0 & 0.0044 & 3.281 & -2.462 to -2.241 & 3.198 to 3.364 & 0.99 & 1.06 \\
\hline & Crossocheilus latius latius $(\mathrm{C})$ & 40 & 9.0 & 15.0 & 12.5 & 0.2481 & 2.455 & -1.766 to -1.022 & 2.116 to 2.795 & 0.85 & 1.03 \\
\hline
\end{tabular}




\begin{tabular}{|c|c|c|c|c|c|c|c|c|c|c|c|}
\hline \multirow{2}{*}{ Family } & \multirow{2}{*}{ Species } & \multirow{2}{*}{$\mathrm{n}$} & \multicolumn{2}{|c|}{ Total length $(\mathrm{cm})$} & \multirow{2}{*}{$\begin{array}{l}\text { Max. known } \\
\text { Length (cm)* }\end{array}$} & \multicolumn{5}{|c|}{ Regression parameters } & \multirow{2}{*}{ K } \\
\hline & & & Min. & Max. & & Anti log a & $\mathrm{b}$ & $95 \% \mathrm{CI}$ of a & $95 \% \mathrm{CI}$ of $\mathrm{b}$ & $\mathrm{r}^{2}$ & \\
\hline & Garra gotyla (A) & 8 & 11.0 & 14.5 & 14.5 & 0.0014 & 3.867 & -3.551 to -2.167 & 3.243 to 4.491 & 0.97 & 1.27 \\
\hline & Garra gotyla (B) & 70 & 5.5 & 15.0 & 14.5 & 0.0084 & 3.206 & -2.260 to -1.907 & 3.026 to 3.386 & 0.95 & 1.32 \\
\hline & Garra lamta $(\mathrm{C})$ & 56 & 13.0 & 21.5 & 15.0 & 0.1328 & 2.058 & -1.196 to -0.558 & 1.799 to 2.317 & 0.82 & 0.93 \\
\hline & Osteobrama vigorsii (A) & 14 & 9.7 & 23.0 & 23.0 & 0.0022 & 3.486 & -3.259 to -2.045 & 2.998 to 3.974 & 0.95 & 0.91 \\
\hline & Osteobrama cotio (A) & 09 & 6.8 & 12.0 & 15.0 & 0.0053 & 3.292 & -2.892 to -1.665 & 2.664 to 3.919 & 0.96 & 1.07 \\
\hline & Systomus sarana $(\mathrm{A})$ & 48 & 6.5 & 25.0 & 42.0 & 0.0104 & 3.105 & -2.095 to -1.870 & 3.006 to 3.203 & 0.99 & 1.38 \\
\hline & Systomus sarana (B) & 52 & 8.2 & 27.0 & 42.0 & 0.0129 & 3.022 & -2.042 to -1.733 & 2.895 to 3.149 & 0.98 & 1.38 \\
\hline & Systomus sarana $(C)$ & 11 & 19.5 & 24.5 & 42.0 & 0.1545 & 2.208 & -1.124 to -0.500 & 1.974 to 2.441 & 0.98 & 1.35 \\
\hline & Puntius sophore (B) & 29 & 6.0 & 10.7 & 18.0 & 0.0109 & 3.104 & -2.300 to -1.621 & 2.722 to 3.486 & 0.91 & 1.36 \\
\hline & Pethia ticto (B) & 25 & 4.0 & 8.0 & 10.0 & 0.0129 & 3.077 & -2.146 to -1.629 & 2.758 to 3.397 & 0.95 & 1.98 \\
\hline & Rasbora daniconius (B) & 71 & 6.5 & 13.0 & 15.0 & 0.0054 & 3.251 & -2.497 to -2.031 & 2.989 to 3.512 & 0.90 & 0.92 \\
\hline Balitoridae & Acanthocobitis botia (B) & 23 & 6.8 & 8.8 & 9.0 & 0.0017 & 3.917 & -3.435 to -2.098 & 3.158 to 4.675 & 0.85 & 1.98 \\
\hline \multirow[t]{6}{*}{ Bagridae } & Mystus bleekeri (B) & 27 & 7.5 & 16.4 & 15.5 & 0.0044 & 3.249 & -2.634 to -2.068 & 2.983 to 3.515 & 0.96 & 0.83 \\
\hline & Mystus cavasius (A) & 15 & 9.5 & 23.5 & 40.0 & 0.0075 & 2.946 & -2.464 to -1.786 & 2.668 to 3.223 & 0.98 & 0.65 \\
\hline & Sperata seenghala (A) & 13 & 21.5 & 50.0 & 150.0 & 0.0040 & 3.043 & -2.676 to -2.115 & 2.861 to 3.225 & 0.99 & 0.47 \\
\hline & Sperata seenghala (B) & 20 & 21.0 & 68.0 & 150.0 & 0.0016 & 3.302 & -3.094 to -2.488 & 3.106 to 3.498 & 0.99 & 0.50 \\
\hline & Rita gogra (A) & 17 & 15.0 & 31.0 & 30.0 & 0.0203 & 2.881 & -1.972 to -1.413 & 2.669 to 3.093 & 0.98 & 1.42 \\
\hline & Rita sp. (A) & 24 & 8.5 & 14.5 & - & 0.0583 & 2.286 & -1.717 to -0.751 & 1.834 to 2.737 & 0.83 & 1.00 \\
\hline \multirow[t]{4}{*}{ Siluridae } & Ompok bimaculatus (A) & 70 & 10.5 & 31.5 & 45.0 & 0.0028 & 3.218 & -2.702 to -2.416 & 3.107 to 3.330 & 0.98 & 0.53 \\
\hline & Ompok bimaculatus (B) & 44 & 16.0 & 43.0 & 45.0 & 0.0029 & 3.207 & -2.887 to -2.182 & 2.945 to 3.470 & 0.94 & 0.55 \\
\hline & Ompok pabda (A) & 08 & 9.0 & 15.1 & 30.0 & 0.0029 & 3.131 & -2.765 to -1.873 & 2.694 to 3.567 & 0.98 & 0.65 \\
\hline & Wallago attu (B) & 17 & 28.0 & 86.0 & 240.0 & 0.0048 & 3.322 & -3.138 to -2.618 & 3.169 to 3.475 & 0.99 & 0.47 \\
\hline Sisoridae & Glyptosternum reticulatum (C) & 08 & 9.5 & 14.4 & 15.8 & 0.1486 & 1.891 & -1.414 to -0.2427 & 1.338 to 2.443 & 0.92 & 1.98 \\
\hline \multirow[t]{3}{*}{ Schilbidae } & Clupisoma sp. (A) & 33 & 8.8 & 40.0 & - & -1.879 & 2.638 & -2.073 to -1.685 & 2.485 to 2.791 & 0.98 & 0.91 \\
\hline & Silonia silondia (A) & 91 & 18.0 & 114.0 & 183.0 & 0.0129 & 2.839 & -2.097 to -1.680 & 2.716 to 2.962 & 0.96 & 0.77 \\
\hline & Silonia childreni (A) & 24 & 21.5 & 43.5 & 48.0 & 0.0443 & 2.401 & -1.671 to -1.037 & 2.178 to 2.623 & 0.96 & 0.95 \\
\hline Pangasidae & Pangasius pangasius (A) & 13 & 29.0 & 78.0 & 300.0 & 0.0094 & 2.932 & -2.514 to -1.543 & 2.644 to 3.221 & 0.98 & 0.97 \\
\hline Claridae & Clarias batrachus (A) & 68 & 9.5 & 25.0 & 47.0 & 0.0259 & 2.485 & -1.748 to -1.426 & 2.340 to 2.630 & 0.95 & 0.70 \\
\hline Heteropneustidae & Heteropneustes fossilis (B) & 35 & 11.5 & 31.7 & 30.0 & 0.0041 & 3.175 & -2.664 to -2.115 & 2.963 to 3.386 & 0.97 & 0.96 \\
\hline Salmonidae & Oncorhynchus mykiss (C) & 14 & 13.5 & 14.0 & 120.0 & 0.0075 & 3.091 & -2.339 to -1.912 & 2.931 to 3.250 & 0.99 & 0.99 \\
\hline Mugilidae & Rhinomugil corsula (A) & 07 & 14.8 & 30.0 & 45.0 & 0.0028 & 3.377 & -2.774 to -2.334 & 3.219 to 3.534 & 0.99 & 0.94 \\
\hline \multirow[t]{2}{*}{ Belonidae } & Xenentodon cancila (A) & 13 & 12.8 & 29.0 & 40.0 & 0.0003 & 3.667 & -4.075 to -2.953 & 3.240 to 4.095 & 0.97 & 0.32 \\
\hline & Xenentodon cancila (B) & 37 & 18.4 & 33.0 & 40.0 & 0.0004 & 3.576 & -3.899 to -2.936 & 3.236 to 3.916 & 0.93 & 0.25 \\
\hline \multirow[t]{2}{*}{ Mastacembelidae } & Mastacembelus armatus (B) & 35 & 8.5 & 59.0 & 90.0 & 0.0077 & 2.640 & -2.334 to -1.897 & 2.491 to 2.789 & 0.98 & 0.22 \\
\hline & Macrognathus pancalus (A) & 05 & 8.8 & 14.8 & 18.0 & 0.2737 & 1.422 & -0.923 to -0.203 & 1.096 to 1.749 & 0.98 & 0.91 \\
\hline \multirow[t]{2}{*}{ Cichlidae } & Etroplus suratensis (A) & 14 & 8.0 & 22.8 & 40.0 & 0.0137 & 3.257 & -2.110 to -1.616 & 3.055 to 3.458 & 0.99 & 2.84 \\
\hline & Oreochromis mosambicus (B) & 08 & 5.0 & 31.5 & 39.0 & 0.0327 & 2.806 & -2.001 to -0.971 & 2.400 to 3.213 & 0.98 & 2.21 \\
\hline Nandidae & Nandus nandus (A) & 10 & 9.9 & 18.9 & 20.0 & 0.0272 & 2.432 & -2.039 to -1.091 & 2.002 to 2.862 & 0.96 & 0.94 \\
\hline Gobiidae & Glossogobius giuris (B) & 31 & 8.4 & 27.0 & 50.0 & 0.0092 & 2.974 & -2.227 to -1.843 & 2.819 to 3.129 & 0.98 & 0.87 \\
\hline \multirow[t]{4}{*}{ Channidae } & Channa marulius (A) & 33 & 19.5 & 67.0 & 183.0 & 0.0058 & 3.061 & -2.394 to -2.086 & 2.958 to 3.163 & 0.99 & 0.71 \\
\hline & Channa marulius (B) & 13 & 18.0 & 74.0 & 183.0 & 0.0092 & 2.949 & -2.222 to -1.852 & 2.836 to 3.062 & 0.99 & 0.76 \\
\hline & Channa punctatus (B) & 17 & 12.0 & 21.5 & 31.0 & 0.0197 & 2.786 & -2.312 to -1.100 & 2.302 to 3.270 & 0.91 & 1.08 \\
\hline & Channa striata (B) & 07 & 23.0 & 41.0 & 100.0 & 0.0081 & 3.002 & -2.799 to -1.378 & 2.543 to 3.462 & 0.98 & 0.82 \\
\hline
\end{tabular}

$\mathrm{N}=$ Total no. of samples, Max. \& Min. $=$ Maximum \& Minimum, $\mathrm{a}=$ Intercept, $\mathrm{b}=$ Slope, $\mathrm{r}^{2}=$ Coefficient of determination

* Available in literature (www.fishbase.org), $\mathrm{K}=$ Condition factor, A = Godavari (Semi-arid zone of Deccan plateau), B = Som River and Jaisamand Lake (arid zone of Aravali hills), $\mathrm{C}=$ Ravi (Upland Himalayan region)

of $\mathrm{b}$ ranged from 1.422 to 3.917 with a mean value of $2.994(\mathrm{SD}=0.471)$ and showed distinct regional variations. The variations in the growth patterns obtained from LWR in this study agreed with those obtained previously by Mendes et al. (2004) from Portuguese west coast; Konan et al. (2007) from south-eastern Ivory Coast; Sani et al. (2010) in rivers Gomti and Betwa, Ahmed and
Saha (1996) in Kapati Lake, Bangladesh; Ramakrishniah (1988) in Nagarjunasagar Reservoir, India, Pet et al. (1996) in Sri Lankan reservoirs, Tah et al. (2012) from two tropical reservoirs and Daliri et al. (2012) from coastal waters in the Northern Persian Gulf. The median values of $b$ were 3.077. Frequency distribution of $b$ values is depicted in Fig. 1. Value of coefficient of determination 


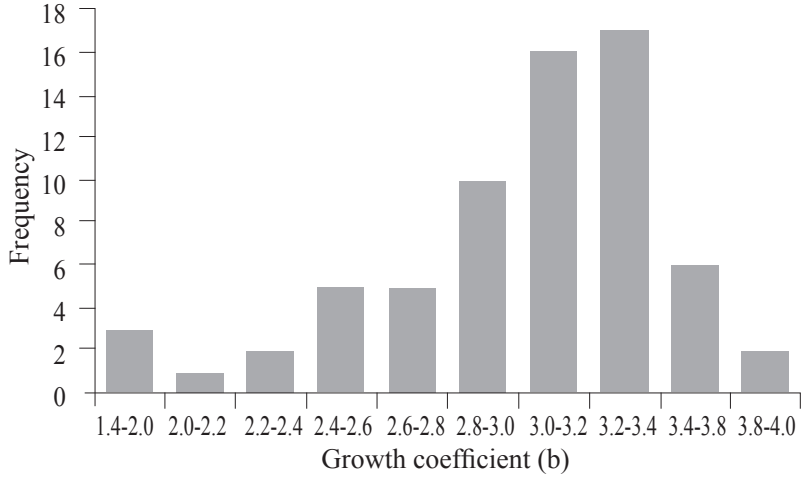

Fig. 1. Frequency distribution of growth coefficient (b) for 57 freshwater fish species from different river systems in India

$\left(\mathrm{r}^{2}\right)$ of the LWR was higher than 0.90 in all the species except for five species viz., Labeo dyocheilus $\left(\mathrm{r}^{2}=0.74\right)$, Crossocheilus latius latius, Acanthocobitis botia $\left(\mathrm{r}^{2}=0.85\right)$, Rita sp. nov. $\left(\mathrm{r}^{2}=0.83\right)$ and Garra lamta $\left(\mathrm{r}^{2}=0.82\right)$. All the linear regressions were highly and statistically significant $(p<0.001)$. Of the 57 species studied, 15 species are listed in the threatened category (endangered EN and vulnerable VU) in India (Lakra and Sarkar, 2006; Lakra et al., 2010) and comparative information on LWR was available only for 24 species in the online database, FishBase (Froese and Pauly, 2013).

In river Ravi, values of $\mathrm{b}$ varied from 1.891 for Glyptosternum reticulatum to 3.145 for Tor putitora; from 1.422 for Macrognathus pancalus to 3.867 for Garra gotyla in Godavari River and from 2.640 for Mastacembelus armatus to 3.917 for $A$. botia in the river Som and Jaisamand Lake. The mean value of $b$ for all eight species in Ravi was 2.548, for 35 species of Godavari were 2.998 and for 24 species of Banas and Som rivers 3.135. The coefficient of determination $\left(\mathrm{r}^{2}\right)$ for species from Ravi River ranged from 0.82 to 0.99 with a median value of 0.95 ; six out of eight regressions presented $r^{2}$ values higher than 0.90. In river Godavari, the value of $\mathrm{r}^{2}$ ranged from 0.74 to 0.99 with a median value of 0.98 and in this river, out of 35 species, 32 species presented $r^{2}$ values higher than 0.95 whereas in river Som and Jaisamand Lake of north-west Rajasthan region, the values of $\mathrm{r}^{2}$ ranged from 0.85 to 0.99 with a median value of 0.97. The LWR of Notopterus notopterus was reported by Parameswaran and Sinha (1966) from ponds and wild tanks of Odisha, and by Sani et al. (2010) from Gomti River in Uttar Pradesh, and the values of regression coefficients (2.97 and 2.95) reported are significantly different from the present values (3.326) estimated from the Godavari River. The highest value of the regression coefficient for G. gotyla was 3.867 in the Godavari River suggesting positive allometric growth of this species in the river. Labeo calbasu, showed isometric growth as reported by Khan (1972) and Sani et al. (2010). The same trend of regression coefficient was also found for two other Cyprinids, Labeo gonius (2.989) and Labeo rohita (3.154) from the Godavari River. These results were similar to the findings of Ahmed and Saha (1996) and Pet et al. (1996). The value of regression coefficient for Ompok bimaculatus was higher in comparison to that reported by Sivakami (1987) from the Bhavanisagar Reservoir in Tamil Nadu. In the family Bagridae, the regression coefficient of Sperata seenghala was almost equal to 3, as reported by Ramakrishniah (1988) from Nagarjunasagar Reservoir. On the contrary, the slope of regression (b) for $M$. armatus was quite low, as reported by Narejo et al. (2003) from Mymensingh, Bangladesh.

The values of $b$ in this study were within the expected range confirmed by Froese (2006). Fish are said to exhibit isometric growth when length increases in equal proportions with body weight for constant specific gravity. According to Hile (1936) and Martin (1949), the value of $b$ usually remains constant at 3.0 for an ideal fish. However, Beverton and Holt (1957) suggested that the departure of the $b$ value from 3 is rare in adult fishes. In the present study, most of the fishes showed deviations from the ideal value. Channa marulius, Tor tor and Xenentodon cancila showed isometric growth whereas Labeo boggut, S. seenghala and O. bimaculatus exhibited positive allometric growth. T. putitora showed growth variation in different ecosystems, isometric in river Som and Jaisamand Lake and positive allometric in river Ravi. The species which were common in ecologically different regions also exhibited different growth stanzas. Systomus sarana exhibited negative allometric growth in Ravi River of upland Himalayan region and isometric growth in arid and semi-arid zones. Out of 35 species from the Godavari river system, growth patterns were isometric, positive allometric and negative allometric for 11, 14 and 9 species respectively. In Som River and Jaisamand Lake, out of 24 species, 17 showed isometric growth, 6 positive allometric and one species showed negative allometric growth. From Ravi River, out of 8 species, 3 showed isometric growth, one positive allometric and 4 negative allometric growth. Overall, 32 estimates $(47.7 \%$ of the total estimates) evidenced isometric growth $(b=3)$, 21 estimates $(31.3 \%)$ showed positive allometric growth (b>3), and 14 estimates (20.9\%) negative allometric growth $(b<3)$. The values of intercept (a) ranged from 0.0003 for $X$. cancila to 0.5393 for $L$. dyocheilus from Godavari River and showed negative correlation with regression coefficient. No published information is available for S. seenghala, Mystus cavasius and Rhinomugil corsula. Comparing the species common in Godavari and Som rivers, it was found that the values of $\mathrm{b}$ in $C$. marulius, T. tor and X. cancila are very close. Similar values of $\mathrm{b}$ in 
these two rivers proved same type of habitat conditions for these species. Species having the standard cyprinid body shape or heavy body (Cirrhinus mrigala, S. sarana and $L$. calbasu) showed different values of $\mathrm{b}$ and growth patterns. Species that are compressed laterally also exhibited some differences in growth pattern, as observed in $M$. armatus, $M$. cavasius and $N$. notopterus. Our observation also indicated a declining trend of maximum growth of the fishes in the rivers as compared to the maximum length already reported (Table 1). Differences in $b$ values can be attributed to the combination of one or more factors viz., number of specimens examined; area seasonal effect; habitat; degree of stomach fullness; gonadal maturity; sex; health and general fish condition; preservation technique and differences in the observed length ranges of the specimens caught (Tesch, 1971; Wootton, 1990).

The values of condition factor of the selected species ranged from $0.22(\mathrm{SD}=0.07)$ for $M$. armatus to 2.84 $(\mathrm{SD}=0.28)$ for Etroplus suratensis with average value of $1.03(\mathrm{SD}=0.44)$ for the 67 estimates of 57 species. The frequency distribution of Fulton's ' $\mathrm{K}$ ' values is presented in Fig 2.

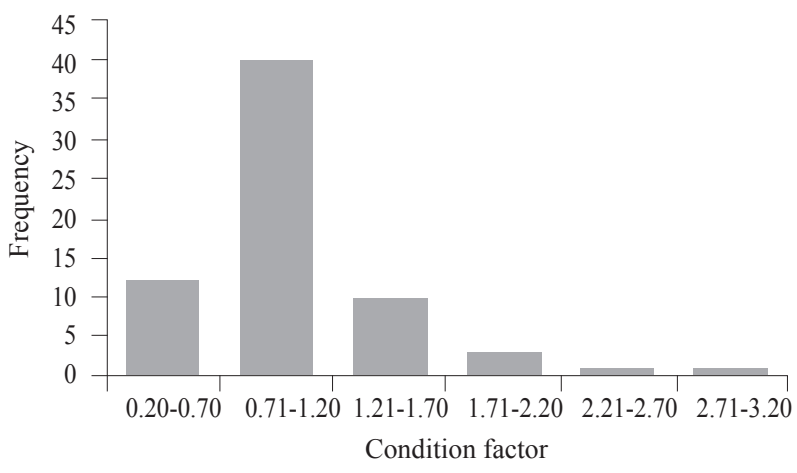

Fig. 2. Frequency distribution of condition factor for 57 freshwater fish species from different river systems in India

The study also showed new record in maximum length of three freshwater fish species viz., C. latius latius (TL 20.8 vs $12.5 \mathrm{~cm}$ ), Rita gogra (31.0 vs $30.0 \mathrm{~cm}$ ) from River Godavari and G. gotyla (21.5 vs 14.5) from Ravi River. Occurrence of these large sized specimens in the regions indicate adequate environmental conditions for their survival and growth as well as low fishing intensity. The ' $\mathrm{K}$ ' values obtained in the present study showed that most of the species studied were in good condition.

The results presented in this study can be a useful baseline resource to enrich fish information inventories and for time series analysis to monitor future changes in ecology and biodiversity trends.

\section{Acknowledgements}

The authors express gratitude to NAIP-GEF (National Agricultural Innovative Projects-Global Environment Fund), New Delhi, India, for providing financial assistance. The authors are thankful to the Director, ICAR-NBFGR, Lucknow for kind support for this work programme.

\section{References}

Ahmed, K. K. and Saha, S. B. 1996. Length-weight relationships of major carps in Kapati Lake, Bangladesh. Naga ICLARM, 19, p. 22.

Anene, A. 2005. Condition factor of four cichlid species of a man-made lake in Imo State, South-eastern Nigeria. Turk. J. Fish. Aquat. Sc., 5: 43-47.

Bagenal, T. B. and Tesch, F. W. 1978. Age and growth. In: Bagenal, T. (Eds.), Methods for assessment of fish production in fresh waters. IBP Handbook vol. 3, Blackwell Science Publications, Oxford, p. 101-136.

Beckman, W. C. 1948. The length-weight relationship, factors for conversion between standard and total lengths, and coefficients of condition for seven Michigan fishes. Trans. Am. Fish. Soc., 75: 237-256.

Beverton, R. J. H. and Holt, S. J. 1957. On the dynamics of exploited fish population. Fish. Invest. Series, 11: 19: 533.

Daliri, M., Paighambari, S. Y., Shabani, M. J. and Davoodi, R. 2012. Length-weight relationship and condition of five marine fish species collected by shrimp trawls in Bushehr coastal waters, Northern Persian Gulf. Afr. J. Agric. Res., 7(28): 4061-4065.

De Silva, K. H. G. M. 1991. Population dynamics and production of the rocky stream-dwelling fish (Cyprinidae) in Sri Lanka. J. Trop. Ecol., 7: 289-303.

Dulcic, J. and Kraljevic, M. 1996. Weight-length relationships for 40 fish species in the eastern Adriatic (Croatian waters). Fish. Res., 28: 243-251.

Ecoutin, J. M. and Albaret, J. J. 2003. Length-weight relationship of 52 fish species from West African estuaries and lagoons. Cybium, 27: 3-9.

Froese, R. 2006. Cube law, condition factor and weight-length relationships: history, meta-analysis and recommendations. J. Appl. Ichthyol., 22: 241-253.

Froese, R. and Pauly, D. 2013. Fish Base. World Wide Web electronic publication. Available at: http://www.fishbase.org, Version 3 (Accessed 20 December 2013).

Fulton, T. W. 1904. The rate of growth of fishes. 22 ${ }^{\text {nd }}$ Annual Report, Part III. Fisheries Board of Scotland, Edinburgh, p. 141-241.

Hile, R. 1936. Age and growth of the cisco, Leucichthys artedi (Lesueur) in the lake of north-eastern highlands Wisconsin. Bull. U. S. Bureau Fish., 48: 311-317. 
Jayaram, K. C. 1999. The freshwater fishes of the Indian region. Narendera Publishing House, New Delhi, 551 pp.

Khan, R. A. 1972. Studies on the biology of some important major carps. Thesis, Department of Zoology, Aligarh Muslim University, Aligarh, 185 pp.

Kohler, N., Casey, J. and Turner, P. 1995. Length-weight relationships for 13 species of sharks from the western North Atlantic. Fish. Bull., 93: 412-418.

Konan, K. F., Ouattara, A., Ouattara, M. and Gourne, G. 2007. Weight-length relationship of 57 fish species of the coastal rivers in South-Eastern of Ivory Coast. Ribarstvo, 65(2): 49-60.

Krause, J., Jean-Guy, J. and Brown, D. 1998. Body length variation within multi-species fish hoals: the effects of shoal size and number of species. Oceologia, 114: 67-72.

Lakra, W. S. and Sarkar, U. K. 2006. Freshwater fish diversity of Central India. National Bureau of Fish Genetic Resources, Lucknow, 200 pp.

Lakra, W. S., Sarkar, U. K., Gopalakrishnan, A. and Pandian, A. K. 2010. Threatened freshwater fishes of India. National Bureau of Fish Genetic Resources, ISBN 978-81-905540-5-3.

Le Cren, E. D. 1951. The length-weight relationship and seasonal cycle in gonad weight and condition in the perch (Perca fluviatilis). J. Anim. Ecol., 20: 530-538.

Lizama, M., DeLos, A. P. and Ambrósio, A. M. 2002. Condition factor in nine species of fish of the characidae family in the upper Parana River floodplain, Brazil. Braz. J. Biol., 62(1): 113-124.

Luff, R. M. and Bailey, G. N. 2000. Analysis of size changes and incremental growth structures in African catfish Synodontis schall (Schall) from Tell el-Amarna, Middle Eygpt. J. Archaeol. Sci., 27: 821-835.

Martin, W. R. 1949. The mechanics of environmental control of body form in fishes. University of Toronto Studies in Biological Series 58. Ontario. Fish. Res. Lab., 70: 1-72.

Mendes, B., Fonseca, P. and Campos, A. 2004. Weight-length relationships for 46 fish species of the Portuguese west coast. J. Appl. Ichthyol., 20: 355-361.

Moutopoulos, D. K. and Stergiou, K. I. 2002. Length-weight and length-length relationships of fish species from the Aegean Sea (Greece). J. Appl. Ichthyol., 18: 200-203.

Narejo, N. T., Rahmatullah, S. M. and Rashid, M. M. 2003. Length-weight relationship and relative condition factor (Kn) of freshwater spiny eel, Mastacembelus armatus (Lacepede) from Mymensingh, Bangladesh. Indian $J$. Fish., 50: 81-87.

Parameswaran, S. and Sinha, M. 1966. Observation on the biology of the featherback, Notoptyerus notopterus (Pallas). Indian J. Fish., 13: 232-250.
Pet, J. S., Gever, G. J. M., Van Desen, W. L. T. and Vijverberg, J. 1996. Management options for a more complete utilisation of the biological fish production in Sri Lankan reservoirs. Ecol. Freshwat. Fish., 5: 1-14.

Ramakrishniah, M. 1988. Age, growth and fishery of Mystus aor (Hamilton) from Nagarjuasagar Reservoir. In: Mohan Joseph, M. (Ed.), Proceedingsof the first Indian Fisheries Forum, Asian Fisheries Society, India Branch, Mangalore, p. 185-198.

Richter, H. C., Luckstadt, C., Focker, U. and Becker, K. 2000. An improved procedure to assess fish condition on the basis of length-weight relationship. Arch. Fish. Mar. Res., 48: $255-264$

Safran, P. 1992. Theoretical analysis of the weight-length relationships in fish juveniles. Mar. Biol., 112: 545-551.

Sani, R., Gupta, B. K., Sarkar, U. K., Pandey, A., Dubey, V. K. and Lakra, W. S. 2010. Length-weight relationships of 14 Indian freshwater fish species from the Betwa (Yamuna River tributary) and Gomti (Ganga River tributary) rivers. J. Appl. Ichthyol., 26: 456-459.

Santos, M. N., Gaspar, M. B., Vasconcelos, P. and Monteiro, C. C. 2002. Weight-length relationships for 50 selected fish species of the Algarve coast (southern Portugal). Fish. Res., 59: 289-295.

Schneider, J. C., Laarman, P. W. and Gowing, H. 2000. Length-weight relationships. In: Schneider, James C. (Ed.), Manual of fisheries survey methods II: with periodic updates. Michigan Department of Natural Resources, Fisheries Special Report 25, Ann Arbor.

Sivakami, S. 1987. Length-weight relationship and relative condition factor in Ompok bimaculatus (Bloch) from Bhavanisagar Reservoir (Tamil Nadu). Indian. J. Fish. 34: $202-207$

Tah, L., GooreBi, G. and DaCosta, K. S. 2012. Length-weight relationships for 36 freshwater fish species from two tropical reservoirs: Ayamé I and Buyo, Cote d'Ivoire. Rev. Biol. Trop., 60(4): 1847-1856.

Talwar, P. K. and Jhingran, A. G. 1991. Inland fishes of India and adjacent countries. Oxford and IBH Publishing Co., New Delhi, 1097 pp.

Tesch, F. W. 1971: Age and growth. In: W. E. Ricker (Ed.), Methods for assessment of fish production in freshwaters, Blackwell Scientific Publications, Oxford, p. 98-130.

Weatherly, A. H. and Gill, H. S. 1987. The biology of fish growth. Academic Press, San Diego, CA, 443 pp.

Wootton, R. J. 1990. Ecology of teleost fishes.Chapman and Hall, London, $405 \mathrm{pp}$.

Zar, J. H. 1984. Biostatistical analysis. Prentice Hall, New Jersey, $718 \mathrm{pp}$.

Date of Receipt $\quad$ : 11.02 .2014

Date of Acceptance : 14.12 .2015 